\title{
CONSERVADORISMO CALEIDOSCÓPICO: EDMUND BURKE E O PENSAMENTO POLÍTICO DO BRASIL OITOCENTISTA*
}

\author{
Christian Edward Cyril Lynch \\ é professor do Instituto de Estudos Sociais e Políticos da Universidade do Estado do \\ Rio de Janeiro (IESP-UERJ) e da Universidade Veiga de Almeida; e pesquisador da Fundação \\ Casa de Rui Barbosa e do CNPq. Rio de Janeiro, RJ. Brasil. E-mail: <clynch@iesp.uerj.br>
}

http://dx.doi.org/10.1590/ 0102-313362/100

O presente artigo examina como foi recepcionada no Brasil oitocentista a obra de Edmund Burke (1729-1797), o propalado "pai do conservadorismo". Como é sabido, a ideologia conservadora teria três núcleos centrais: (1) a preocupação com o controle da mudança, que não deveria ocorrer a partir exclusivamente da intervenção deliberada da razão ou ação humana, sob pena de gerar caos ou entropia; (2) a "crença nas origens extra-humanas da ordem social, entendida como independentes da vontade humana"; e (3) a organização defensiva de seu sistema teórico ou substantivo, adaptando-se ao adversário de modo a espelhar de modo simétrico, mas negativo, as suas respectivas posições. Daí sua flexibilidade (Freeden, 1996, p. 334).

Entretanto, ao contrário do que possa parecer à primeira vista, meu interesse não é o de limitar-me ao mero estudo da recepção da obra de Burke, nem o de investigar os supostos bons ou maus usos de seu pensamento pelos

Agradeço a Bernardo Ricupero, Ivo Coser e Paulo Henrique Cassimiro pela leitura atenta de versões anteriores deste texto. Seus comentários foram valiosos e muito ajudaram a melhorá-lo. 
brasileiros. Esta última é uma questão que, do ponto de vista metodológico de uma história dos conceitos e dos discursos políticos, simplesmente não faz sentido (Palti, 2012). Trata-se antes de averiguar o que o estudo da recepção de Burke pode revelar sobre o "conservadorismo" brasileiro no contexto mais amplo de nossa cultura política, entendida como "o conjunto de atitudes, normas, crenças, mais ou menos largamente partilhadas pelos membros de uma determinada unidade social e tendo por objeto fenômenos políticos" (Sani, 1998, p. 306) ${ }^{1}$. Sigo aqui nomeadamente a sugestão de Drew Maciag, para quem o estudo da recepção de um grande autor em um país distinto daquele originário de sua produção pode descortinar "um pano de fundo mais profundo sobre as ideias em disputa, as cosmovisões, os preconceitos e os quadros de referência, que informam e controlam os elementos mais autoconscientes" do campo político e cultural onde se processa a referida recepção 314 (Maciag, 2013, p. XI) ${ }^{2}$. Este parece ser também o interesse da recentíssima coletânea que acaba de ser publicada sobre a recepção de Burke na Europa, envolvendo países tão diversos quanto Irlanda, Espanha, Alemanha e Hungria (Fitzpatrick e Jones, 2017).

Para os fins deste artigo, concentrei-me em cinco autores representativos do primeiro século de política brasileira, os quais, em seus escritos, mobilizaram a autoridade de Burke. Os três primeiros eram declaradamente conservadores: José da Silva Lisboa, Visconde de Cairu (1756-1836), Bernardo Pereira de Vasconcelos (1795-1850) e José Martiniano de Alencar (1829-1877); os dois últimos, liberais: Rui Barbosa (1849-1923)

\footnotetext{
1 Uma cultura política é atravessada por ideologias ou discursos políticos, entendidos como complexos de "ideias, crenças, opiniões e valores que exibem um padrão recorrente; que possuem grupos significativos como seus portadores; competem pelo fornecimento e controle das políticas públicas, com o objetivo de justificar, contestar ou alterar os processos e arranjos políticos e sociais de uma comunidade política" (Freeden, 2003, p. 32).

2 Todas as traduções de citações em língua estrangeira foram feitas pelo autor.
} 
e Joaquim Nabuco (1849-1910). Neste último caso, a pesquisa permitiria esclarecer qual a relação que o liberalismo poderia eventualmente entreter com o conservadorismo. A conclusão aponta duas direções. Em primeiro lugar, ela destaca os dilemas conservadores no Brasil, cujo grau percebido de atraso civilizacional impelia seus adeptos a lançarem mão de argumentos mais progressistas do que seria de esperar em outros contextos (Lynch, 2008, 2015; Ricupero, 2010). Em segundo lugar, evidencia-se a complexidade daquele conceito, empregado ao longo do período para designar atitudes que, a despeito de sua proximidade, não podem ser colocadas no mesmo saco. Não há conservadorismo, mas conservadorismos; da mesma forma, eles nem sempre se harmonizam, frequentemente competindo e entrechocando. Reformismo ilustrado, conservadorismo estatista, conservadorismo culturalista e liberalismo conservador são nuanças que um estudo consequente das ideologias ou linhas de pensamento político brasileiro precisa considerar.

\section{A obra de Burke no contexto do lluminismo britânico}

Segundo a narrativa consagrada nos manuais, a bíblia do conservadorismo teriam sido as famosas Reflexões sobre a Revolução em França (1790). Edmund Burke teria sido seu pontífice máximo, tanto quanto Locke seria do liberalismo e Marx, do socialismo. A "ideologia conservadora" teria surgido como reação ao ideário iluminista dos intelectuais europeus, a partir de um movimento sediado originalmente na França e ao qual a Grã-Bretanha teria ficado indiferente. Nada mais natural, assim, que esta última tenha servido de "berço" do conservadorismo (Venturi, 2003). Esses são lugares-comuns que precisam ser questionados.

Preliminarmente, cumpre dizer algo acerca das análises das recepções no tempo e no espaço, especialmente em um contexto periférico como o brasileiro do século XIX. A recepção de uma obra "clássica" não depende apenas da agenda dos atores locais e da cultura política em que estão imersos, 
mas do prestígio gozado pelo autor em seu meio de origem e da interpretação que ali lhe conferem. Ademais, depois da recepção inicial, a obra sofre sucessivas reinterpretações, também relacionadas com aquelas que vão tendo lugar em seu contexto originário. Em outras palavras, há sucessivas recepções das reinterpretações sofridas pelas obras dos autores. Essas considerações são importantes para nos acautelarem contra a tendência dos manuais de apresentarem determinadas obras como arquétipos de ideologias perfeitamente definidas, coerentes ao longo do tempo e do espaço.

A hipótese de uma Grã-Bretanha infensa ao Iluminismo, por sua vez, tem sido desafiada por historiadores para os quais a modernidade não teria sido um fenômeno unificado, variando conforme os processos de secularização de cada país. Na França setecentista, os privilégios da Igreja teriam levado à emergência de um anticlericalismo que pregava rupturas radicais com os padrões de pensamento (reli316 gião) e de ordem política (despotismo). Já do outro lado da Mancha, as transformações puderam ser pensadas pelo Iluminismo como um processo de expansão das liberdades dentro da ordem preestabelecida, associado ao desenvolvimento da economia e dos costumes (Himmelfarb, 2005, p. 72). O absolutismo inglês já havia sido derrotado em proveito de uma forma embrionária e oligárquica de governo representativo. Com o intuito de compreender a natureza da sociedade civil que emergia no bojo da expansão comercial do Império e do fortalecimento do mercado mobiliário e financeiro, intelectuais como David Hume, Adam Ferguson e Adam Smith investigaram as causas da mudança política, social e econômica (Pocock, 1985). Os clérigos não compunham um estamento privilegiado e já se gozava de relativa liberdade de cultos (Pocock, 2003, pp. 7 e 150). Assim, o Iluminismo britânico pôde pensar a sociedade civil como um organismo que se desenvolvia e se aperfeiçoava a partir do comércio e dos costumes. Adquiriu, assim, contornos 
moderados e conciliadores, equilibrando religião institucional e tolerância política em torno da noção de senso moral.

Também é historicamente problemática a associação entre Burke e um conservadorismo perfeitamente distinto do liberalismo. O estudo profissional das ideologias só se difundiu na Europa na década de 1930, na esteira da publicação de Ideologia e utopia, de Karl Mannheim, que pressupunha uma ideologia conservadora distinta da liberal (Mannheim, 1968). Válida para a conjuntura burocrática e reacionária da Alemanha oitocentista, a distinção não parece sê-lo, porém, naquela da Grã-Bretanha, cujos primeiros estudos sobre ideologias políticas, como os de Harold Laski (publicado em 1936), ainda não ousavam fazer uma separação tão marcada ${ }^{3}$. A imagem de Burke como pai de uma "ideologia conservadora" perfeitamente clara e definida seria estabelecida nos Estados Unidos somente no começo da Guerra Fria, quando o movimento neotradicionalista de influência católica (hoje chamado paleoconservador) estava em busca de um "patrono" respeitável em sua luta contra o socialismo e o liberalismo. Seus intelectuais orgânicos, como Russell Kirk, divulgaram então interpretações de Burke que o retratavam mais parecido com aqueles que o invocavam - e, portanto, mais "conservador" do que ele havia sido efetivamente (Maciag, 2013, p. 184) ${ }^{4}$. Foi esse Burke que passou aos manuais de ciência política (por exemplo, Watkins e Kramnick, 1981, pp. 30-32).

\footnotetext{
3 Por esse tempo, Laski (1973, pp. 141-42) não hesitava em conferir a Burke um lugar de honra no panteão dos liberais: "Se a tônica fundamental de Burke é conservadora, a base utilitarista do seu credo, entretanto, continha elementos suscetíveis de uma interpretação liberal."

4 Assim, por exemplo, Gabriel Trigueiro (2016) se refere à biografia de Burke escrita por Russell Kirk, um dos principais ideólogos do paleoconservadorismo norte-americano: "Para quem teoricamente possuía uma agenda baseada na história e na experiência concreta, Russell Kirk recorre com frequência demasiadamente incômoda a uma memória seletiva e a uma sensibilidade romântica, a fim de criar uma coesão discursiva e analítica e apresentar um Burke alquebrado, politicamente útil, mas historicamente falsificado".
} 
Uma vez que o estudo da recepção de Burke fora da Grã-Bretanha não pode ser efetuado ignorando o contexto histórico de sua produção, cumpre gastar mais algumas linhas em esclarecer o assunto. No século XVIII, quando Burke desenvolveu sua carreira e obra, não havia conceitos como liberalismo e conservadorismo, mas duas denominações referentes às facções parlamentares em pugna: whig e tory. Identificados com os interesses da grande aristocracia agrária, os tories compunham um "partido da ordem", conhecido por sua "reverência instintiva pelo que estava estabelecido, o respeito pelo governo e pela Coroa, uma lealdade em face da Igreja da Inglaterra e um preconceito em prol do interesse agrário" (Watts, 2002a, p. 3).Já os whigs se identificavam com a ala mais progressista da aristocracia rural e a nova sociedade civil, descritos à época pelo próprio Burke (1993, p. 149) como a "alta nobreza, os grandes proprietários de terras, os opulentos mercadores e industriais e os pequenos fazendei318 ros da classe média”. O autor das Reflexões sobre a revolução em França não pertencia às fileiras dos tories, mas às dos whigs, cujo discurso, diferentemente, se caracterizava pela defesa do governo parlamentar e das minorias religiosas, conformando "uma tradição de liderança aristocrática do movimento reformista" (Watts, 2002b, p. 7). É nessa qualidade que seu pensamento deve ser examinado em seu conjunto.

Para Burke, a política não era uma ciência abstrata, racionalista e universalista, mas uma arte voltada para a resolução de problemas práticos. $\mathrm{O}$ estadista não era um especulador metafísico, mas "um filósofo em ação" (Burke, 1993, p. 187). A fim de preservar a tolerância indispensável ao compromisso, o político precisava resistir às paixões que levavam os homens à anarquia ou ao despotismo: "Todo governo, de fato todo benefício e gozo humanos, toda virtude e todo ato prudente, é fundado em compromisso e troca" (Burke, 1993, p. 237). Daí a precaução contra a "ilusória precisão geométrica em matéria de argumentos 
morais" (Burke, 1993, p. 258). O mesmo espírito orientava o estadista encarregado de promover reformas: em vez de um radicalismo típico da "intemperança do intelecto", ele deveria optar por um "emprego dos materiais preexistentes" que lhe permitisse manter a previsibilidade dos acontecimentos. Burke também aprendera com Montesquieu que cada nação - Inglaterra, Irlanda, América, Índia, França possuía ecologias próprias, que condicionavam o ritmo da ação política: regras ou posturas que funcionavam em certos tempos e lugares não funcionavam em outros. Mais um motivo pelo qual, em vez de seguir esquemas apriorísticos, o bom político agia de modo prudente, isto é, guiado por uma experiência pessoal esclarecida pelo conhecimento histórico e pela avaliação cuidadosa das circunstâncias em que sua ação teria lugar (Burke, 1992, p. 232).

A finalidade última da atividade do estadista virtuoso tinha em vista a preservação e a expansão das liberdades pela reforma dentro da ordem estabelecida. Entretanto, como a política não era uma linha reta, para alcançar esse fim, ele precisava frequentemente trilhar caminhos tortuosos: "Nossa Constituição repousa sobre um belo promontório, cercado por precipícios íngremes e águas profundas em todos os lados. Ao removê-la de uma inclinação perigosa para um lado, pode haver risco de precipitá-la, por outro" (Burke, 1993, p. 190). Sua sensibilidade whig continha tanto elementos "liberais" quanto "conservadores"; eram as circunstâncias concretas que determinavam quais prevaleceriam sobre sua percepção do mundo. Daí o seu pendor para o equilíbrio das coisas: quando a autoridade ameaçava se tornar despótica, era legítimo criticá-la para defender a liberdade. Burke o fizera durante a primeira metade de sua carreira, ao combater a oligarquia cortesã de Jorge III; ao defender os colonos norte-americanos contra as pretensões centralizadoras da metrópole e ao denunciar os abusos da administração imperial na Índia. Entretanto, quando era o excesso de liberdade, 
tornada licença, que ameaçava a ordem com a anarquia, cumpria defender as instituições contra o risco de subversão ${ }^{5}$. Foi efetivamente o que aconteceu em 1790, diante da ameaça de radicais como Thomas Paine e Richard Price (os "novos whigs"). Burke publicou então as Reflexões sobre a Revolução na França e passou a apoiar, contra o próprio partido, a coalizão tory que sustentava o governo de William Pitt contra as simpatias de seus correligionários pelo ideário universalista e abstrato da Revolução Francesa.

Nas Reflexões, Burke sustentava que o sistema social era sagrado, como parte de uma cadeia de ordem eterna ligando o homem a Deus; natural, porque parte da lei implantada por Deus na mente humana; histórico, produto de um progresso social orgânico; e, por fim, tradicional, fundado em costumes e precedentes britânicos marcados por lenta e prescritiva adaptação (Pocock, 1987, p. XIV). Embora seja tentador crer que, na ocasião, Burke teria passado ideo320 logicamente de whig a tory, a resposta não é tão clara quanto parece. A despeito das simpatias de Pitt por suas ideias ele mesmo era um antigo whig (Watts, 2002a, p. 6) -, a verdade é que os tories as refugaram por não as julgarem suficientemente comprometidas com a defesa do establishment (Pocock, 1987, p. XL). Ou seja, os próprios tories da década de 1790 não consideraram as ideias de Burke suficientemente "conservadoras". E tinham lá suas razões. As Reflexões assinalavam menos uma mudança de orientação do que a acentuação da importância de elementos, até então em segundo plano, relativos à defesa da ordem que tornava a liberdade possível na Grã-Bretanha. Em vez de inventar o conservadorismo, que já existia em sua forma tory, Burke

\footnotetext{
5 "Sempre que o fiel da balança se deslocava com muita velocidade para um lado, Burke tratava de ajustar o peso para o outro [...]. Todas as vezes que ele percebeu haver uma pronunciada inflexão conservadora no mainstream político, ele recorreu a um discurso e a ações políticas progressistas. O contrário é igualmente verdadeiro" (Trigueiro, 2017, p. 54).
} 
criou, na verdade, uma versão conservadora do liberalismo whig, que tinha muito de circunstancial e de tática. Conforme reconhecido por seu primeiro grande biógrafo (Morley, 1888, p. 109), ele mudara de frente de combate sem trocar de terreno. Em outras palavras, continuava no campo whig.

Radicalizados em relação à Revolução e às guerras napoleônicas, nem whigs nem tories se interessaram de imediato pela obra do publicista irlandês. A situação só mudou de figura na década de 1820, muito depois de sua morte - em 1797 (aos 68 anos), quando as guerras terminaram e foi possível à classe política como um todo perceber quão modificadas estavam as condições do país devido ao processo de urbanização, com o agravamento das condições de vida da população e o fortalecimento de facções radicais. Os tories deram um passo adiante e passaram a se chamar conservadores, para - nas palavras de seu líder à época, Robert Peel - tornar o partido "compatível com reformas cautelosas e bem digeridas em cada instituição que realmente requeira reformas" (apud Watts, 2002a, p. 48). Nesse processo, o conservadorismo liberal de Burke, pós-1790, foi incorporado ao repertório dos tories reformistas para reforçar a positividade de "mudanças dentro da ordem" (Watts, 2002a, p. 15). Por sua vez, amedrontados pelos radicais, os whigs passaram a se intitular whigs liberais, ou simplesmente liberais, e a fazer a apologia de reformas periódicas e bem temperadas (Watts, 2002b, p. 12). Whigs ilustres como Macauley entronizaram então o liberalismo moderado de Burke ("old whig"), anterior à década de 1790, elogiando-a como uma "nobre ciência da política", que teria caracterizado a ação do partido desde suas mais remotas origens (Macaulay, 1978, p. 128). Foi assim que o consenso moderado que passou a vigorar na cultura política britânica oitocentista assumiu a forma de um

[...] burkeanismo difuso, com suas referências à ideia de que instituições políticas bem-sucedidas resultavam de reformas lentas; sua imagem favorita da mudança constitucional 
como promoção de reparos e acréscimos paulatinos a uma antiga construção herdada, e sua recomendação do respeito pela tradição como parte fundamental da sabedoria política (Collini, Winch e Burrow, 1983, p. 20).

\section{Crise do Antigo Regime e absolutismo ilustrado: o Burke "cosmopolita" do Visconde de Cairu}

Como, porém, foi a obra de Burke - em especial, as Reflexões sobre a Revolução em França - recepcionada fora do seu contexto originário? Embora sua popularidade fosse reduzida na Grã-Bretanha durante as duas primeiras décadas posteriores à publicação, na América e na Europa continental o livro obteve retumbante êxito, tendo sido publicado nos três anos seguintes nos Estados Unidos, França, Alemanha e Itália (Pocock, 1987, pp. XL-XLI).

Aqui também é preciso cautela. Embora surjam em luga322 res determinados, os conceitos e as linguagens políticas são essencialmente móveis e, transpostos para sociedades diferentes, tendem a apresentar uma operacionalidade diversa. Por isso, o estudo da recepção de certa obra depende sempre da compreensão do tempo e do lugar dos personagens envolvidos e sua respectiva cultura política. Segundo Pocock (1987, p. XLVI):

Qualquer pensador que pretenda valer-se de uma estratégia burkeana precisa perguntar-se em que sociedade aquela estratégia será levada a efeito; qual é o "passado" daquela sociedade, ou seja, os processos de mudança e preservação pelos quais a sociedade tornou-se o que é; qual (se houver) o grau de compromisso desta sociedade com o seu passado, isto é, quais as condições insuscetíveis de mudanças, sob pena de a sociedade se tornar irreconhecível a si mesma; e, caso haja revolucionários bastante dispostos a mudar a sociedade tão inteiramente, de modo a torná-la 
irreconhecível, indagar-se em que grau aquele objetivo pode ser perseguido. É provavelmente a natureza do "passado" e do "compromisso" que vão diferenciar o conservadorismo de uma sociedade para outra. E a questão estará bastante complicada devido ao fato de que o "passado" de muitas sociedades incluem, agora, a experiência da revolução.

É o que, efetivamente, se percebe do exame perfunctório da recepção das Reflexões nos Estados Unidos. Na América independente, o horizonte da política estava todo deslocado para o futuro. Impôs-se no imaginário a ideia do excepcionalismo americano, de que aquela era uma terra virgem, explorada pelo esforço consciente e concertado de homens dispostos a criar um mundo não somente novo, mas melhor; que o povo americano estava destinado a guiar os demais para o futuro através do exemplo virtuoso (Maciag, 2013, p. 26). Como ingleses americanos, renegavam as velhas tradições do Velho Mundo para criarem novas e delas viverem. Nesse quadro, a ideologia dominante tinha de ser um liberalismo livre de toda e qualquer amarra conservadora. Nas colônias americanas, onde não havia aristocracia agrária nem Igreja estabelecida, o liberalismo democrático de Paine assumiria ares de "ideologia natural" (Hartz, 1991). Em decorrência disso, nos Estados Unidos, um torismo como o britânico seria impossível, e o próprio whiguismo, malvisto por seus contornos aristocráticos e paternalistas. O conservadorismo só pôde vicejar no momento de construção nacional, quando o radicalismo estadualista pôs em risco a existência da União e foi possível a membros do Partido Federalista (isto é, unionista), como Alexander Hamilton e John Adams, apelar a autores do Iluminismo britânico, como Hume, para justificar a Constituição de 1787. Tiveram de fazê-lo, porém, sem abdicarem de premissas universalistas e democráticas, mantendo um difícil equilíbrio teórico entre Burke e Paine (Maciag, 2013, p. 40). Mas mesmo este foi um breve 
interlúdio. A partir das presidências de Jefferson e Andrew Jackson, consagrou-se o já mencionado imaginário de uma nação liberal e democrática, cujo destino era manifesto, ao qual o conservadorismo, saudoso das origens britânicas, nunca pôde se acomodar (Wood, 2009).

Se a cultura política estadunidense era refratária a qualquer tipo de conservadorismo e mesmo ao liberalismo moderado, aquela da França revolucionária também criaria obstáculos para a recepção de Burke. A alternativa intermédia de um liberalismo tolerante e moderado, de inspiração inglesa, havia sido eliminada pelos radicais logo no primeiro ano da Constituinte, reputada incompatível com a cultura do país ${ }^{6}$. Nela, a luta opunha a antiga aristocracia privilegiada e a população rural, reunidas em torno da tradição monárquica católica, à pequena burguesia urbana e aos profissionais liberais, que brandiam uma ideologia democrática radical (Furet, 1988). Nesse ambiente, foram reacionários como De Maistre e De Bonald 324 que absorveram as reflexões burkeanas críticas ao jusnaturalismo abstrato; e elogiosas do papel civilizador da tradição e da religião. Quando, a partir do Termidor (em 1795), o liberalismo moderado de Madame de Staël e Benjamin Constant tentou cavar um espaço entre o radicalismo republicano e o reacionarismo absolutista, os argumentos de Burke continuaram problemáticos. Uma vez que a liberdade moderna inexistia na França do Antigo Regime, os liberais não tinham como esconjurar a Revolução que a trouxera em suas turvas águas. Era preciso assim equilibrar a veneração pela monarquia tradi-

${ }^{6}$ Refiro-me aqui ao grupo, chamado partido monarquiano, defensor por excelência da proposta de instauração, na França revolucionária, de uma Monarquia constitucional e representativa, inspirada na Constituição da Inglaterra, ancorada nas teorias veiculadas por Montesquieu de governo misto, da separação de poderes e dos freios e contrapesos (Griffiths, 1988; Lynch, 2011). Foram os únicos revolucionários que escaparam da completa condenação por parte de Burke: "Aqueles que consideram Mounier e Lally como desertores devem se considerar a si mesmos assassinos e traidores: de quem além do assassinato e da traição eles teriam desertado? De minha parte, eu os honro por não terem convertido o erro em crime" (Burke, 1992, p. 61). 
cional com uma teoria do progresso histórico que incorporava as conquistas de 1789 e limitava a autoridade régia, definindo-a como um poder neutro (Courtney, 2017; Col, 2017). Na história das ideias francesas, Burke acabou, assim, identificado a um tradicionalismo antiliberal, que era mais conservador do que o dos próprios tories (Raynaud, 1993, p. 188).

Tais considerações são relevantes para se compreender a recepção de Burke no Brasil. Governado pelo Príncipe Regente Dom João, o Império luso-brasileiro de 1812 era uma periférica e colonial sociedade do Antigo Regime aparentemente imune ao vírus revolucionário. Tratava-se de uma comunidade tradicional, rural e analfabeta, dispersa por um imenso território despovoado, quase inacessível aos agentes do Estado. Instituições como escolas de medicina e de engenharia, ou a imprensa - ainda que submetida à censura eram novidades recentíssimas. Parte substantiva da população era composta de africanos escravizados, trazidos desde o início da colonização para suprir a carência de mão de obra barata. A esfera pública era mínima e apresentava um viés fortemente aristocrático: mesmo os pobres livres eram senhores de escravos e não exageravam suas diferenças em relação às classes superiores. Nesse país, marcado por um Antigo Regime colonial, que não era liberal democrático como os Estados Unidos, nem liberal moderado como a Inglaterra, nem jacobino como a França revolucionária, qual poderia ser a funcionalidade da obra de Burke?

A resposta está na percepção, por parte da elite dirigente da Monarquia luso-brasileira, de que ela era tão periférica e atrasada que a simples manutenção do status quo lhe ameaçava a sobrevivência. Esse diagnóstico era compartilhado desde a metade do século XVIII por outras monarquias, como Rússia, Prússia, Espanha, Áustria e o Reino de Nápoles, e ensejara, como consequência, as diversas experiências de modernização pelo alto que vieram a ser conhecidas como despotismo ou absolutismo ilustrado (Bluche, 2000). 
Ciente da extrema debilidade do Império português - como, antes dele, seu padrinho, o Marquês de Pombal -, Dom Rodrigo de Sousa Coutinho, Conde de Linhares, ministro progressista de Dom João, defendia "luminosas reformas executadas por homens inteligentes e capazes de formar sistemas bem organizados, e cuja utilidade seja, por todos, sentida e experimentada" (Maxwell, 2001, p. 235). Temeroso das turbulências revolucionárias que já atingiam os vizinhos do continente americano, Dom Rodrigo apostava num reformismo que passava pela "racionalização dos conjuntos imperiais mediante a intervenção direta do poder central, seja através do fomento, seja através do controle da atividade produtiva (mediante proibições), seja através dos circuitos de distribuição (mediante monopólios)" (Jancsó, 2002, p. 8). A Monarquia deveria antecipar-se às eventuais pressões que surgiriam na sociedade, satisfazendo-as na medida de suas conveniên$\operatorname{cias}^{7}$. Foi essa lógica de prevenção da revolução e semeadura 326 das teses de mudança gradual, "despertada pela autoconsciência de uma inédita aceleração histórica no mundo luso-americano" (Sanches, 2015, p. 106), que presidiu a recepção das ideias de Burke no Brasil a partir da década de 1810. A difusão antecipada dos ideais iluministas britânicos serviria para prevenir a disseminação do radicalismo, acenando, em seu lugar, com a possibilidade de um reformismo lento e gradual, menos fatal às instituições.

O principal artífice da recepção de Burke e outros autores do Iluminismo britânico foi o jornalista, economista e político baiano José da Silva Lisboa (1756-1835), futuro Visconde de Cairu. Secretário da Mesa da Inspeção

\footnotetext{
7 Apenas a adoção de reformas ilustradas por parte do próprio Estado poderia assegurar "o sacrossanto princípio da unidade, primeira base da Monarquia que se deve conservar com o maior ciúme, a fim de que o português nascido nas quatro partes do mundo se julgue somente português; e não se lembre senão da glória e grandeza da Monarquia, a que tem a fortuna de pertencer, reconhecendo e sentindo os felizes efeitos da reunião de um só todo, composto de partes tão diferentes que, separadas, jamais poderiam ser igualmente felizes" (Lyra, 1994, p. 69).
} 
da Bahia, desde 1801 ele vinha publicando diversas obras em Portugal, tais como os Princípios do direito mercantil e leis da Marinha; os Princípios de economia política; e as Observações apologéticas acerca da crítica que faz contra Smith o autor das "Memórias políticas sobre as verdadeiras bases da grandeza das nações". Quando da chegada da família real, ele fizera circular as suas Observações sobre a franqueza do comércio (de 1808), que justificavam intelectualmente a decisão de encerrar o sistema de monopólio comercial e abrir os portos à Inglaterra e aos Estados Unidos.

A tradição e os costumes, tão valorizados na reflexão de Burke com relação à Inglaterra, tinham como referência, em Silva Lisboa, a tradição monárquica portuguesa na sua versão pombalina. Tradição essa que configurava um quadro complexo, uma vez que nela coexistiam os elementos novos que apontavam em direção a um modelo político voluntarista e os remanescentes da antiga tradição corporativista (Kirschner, 2003, p. 691).

Tratava-se de promover reformas dentro da ordem, de modo a elevar o Brasil, do ponto de vista civilizacional, contra o conservadorismo sistemático da ala reacionária da Corte joanina. Era o que defendia em seus textos:

Não nos persuadamos que os nossos maiores nos deixaram todas as possíveis lições de sabedoria. Adotemos da antiguidade o que é bom, e venerável, e não o que se mostra irracional e caduco. Quando a órbita política torneia com tão vertiginoso movimento, é absurdo ficar-se estacionário, e não se seguirem novas regras. Quando o vento salta à proa, o bom piloto muda logo de rumo (Visconde de Cairu, 2001, p. 194).

Assim notabilizado por seus talentos, Silva Lisboa foi encarregado pelo Conde de Linhares, em 1812, de traduzir 
e publicar os Extratos das obras políticas e econômicas do grande Edmund Burke. A publicação visava

[...] assoalhar algumas amostras dos pensamentos deste insigne mestre de ciência prática da administração e de política ortodoxa [i.e., Burke], por ser o mais valente antagonista da seita revolucionária e o que, ensinando realidades e não quimeras, expôs os verdadeiros direitos do homem, lançando exata linha divisória entre as ideias liberais de uma regência paternal e as cruas teorias de especuladores metafísicos, ou maquiavelistas, que têm perturbado ou pervertido a imutável ordem social, estabelecida pelo Regedor do Universo (Lisboa, 1822, pp. V-VI).

Nesta qualidade, o livro poria à disposição do público um autêntico "antídoto contra o pestífero miasma e sutil veneno das sementes da anarquia e tirania da França, que 328 insensivelmente voam por bons e maus ares, e por todos os ventos do globo" (Lisboa, 1822, p. V). O futuro visconde não escondia seus adversários doutrinários: "Rousseau e Condorcet, Mirabeau e Mably não são meus homens" (apud Neves, 2003, p. 346). Repise-se, todavia, que Silva Lisboa não se colocava em tais textos como inimigo da mudança, mas da revolução. Como tal, não apresentava Burke como um reacionário, mas como um sábio cosmopolita e moderno que prescrevia o modo certo de reformar as instituições:

Burke judiciosamente observou que não se precisava de talento, nem de sagacidade fora do comum, para notar irregularidades na regência dos Estados, e os abusos dos nobres, ricos e administradores públicos: a questão só é sobre os oportunos remédios de prevenir os dados e emendá-los. Execrar revoluções não é defender desgovernos, nem excluir boas leis. Ainda os melhores soberanos e administradores são obrigados a conformarem- 
se às opiniões das diversas ordens do Estado. Quando o remédio é pior que o mal, até as boas reformas são inúteis ou nocivas. As revoluções são como os terremotos: tudo arruínam e nada reparam. A sociedade civil, depois de convulsões políticas, sempre torna a recompor-se de ricos e pobres, nobres e plebeus; bons e maus; quem mande e quem obedeça. A cena será renovada e unicamente mudarão os atores. Só a doce influência da verdadeira religião e o progresso da cultura do espírito podem diminuir erros e vícios dos homens e fazer durar e florescer os impérios. Mas a perfeição ideal é de absoluta impossibilidade. Que se ganha com as revoluções? As ambições desordenadas se desenfreiam. É preciso confiar a força pública de novas mãos e concentrá-la na de poucos ou de algum, para resistir-se aos inimigos internos e externos. Eis organizada a oligarquia, que logo finda em ditadura e tirania. Tal é o desfecho das revoluções antigas e modernas; e, em algumas, o despotismo se firmou para sempre (Lisboa, 1822, pp. VI-VII).

Por ocasião da Revolução constitucionalista e da independência, dez anos depois, o futuro visconde publicaria, em seu Roteiro brasílico ou Coleção de princípios e documentos de direito público, textos de outros autores ligados ao Iluminismo britânico, como Hume, Montesquieu, Staël, Ferguson e o próprio Burke. Todos se opunham a mudanças bruscas ou movidas pelo puro racionalismo. Foi invocando suas autoridades que Silva Lisboa faria a apologia do reformismo social e econômico, nele inclusa a condenação do escravismo, mas ressalvada a autoridade da Monarquia centralizada. Conforme o liberalismo brasileiro foi se radicalizando ao longo do reinado de Dom Pedro I, sua posição relativa se tornou mais caracteristicamente conservadora, passando ele a temer que reformas radicais abrissem "o compasso das inovações, dando vasto e ilimitado arbítrio aos deputados para tratarem o Brasil como tábua rasa, e auto- 
rizar e provocar a convocação de uma convenção nacional" (ASI, 15/6/1832). Ainda assim, sua defesa da Monarquia e da centralização política não pode ser assimilada a uma pura defesa do status quo, na medida em que, ao contrário do que se passava com diversos representantes de posições mais avançadas, Cairu continuava a vincular a defesa daquelas instituições à necessidade de civilizar o país e abolir a escravidão. A escravatura representava o "compêndio de todos os males, e o emblema e prova da depravação do homem, que ou não quer trabalhar, ou se apraz do espetáculo da violência e miséria alheia" (apud Martins, 1974, p. 108). Em síntese: por meio da aclimatação das teorias e argumentos de Smith e Burke, Silva Lisboa adaptava de modo pragmático o liberalismo britânico à realidade brasileira, para assim, alardeando a sua vocação "cosmopolita", elaborar para o Antigo Regime português "um projeto político e cultural que enfrentasse os tempos modernos" 330 (Araújo e Pimenta, 2009, p. 127).

\section{Crítica do liberalismo cosmopolita e construção do Estado nacional: o Burke "particularista" de Bernardo Pereira de Vasconcelos}

Rompendo os laços políticos formais com a Europa, a independência do Brasil tornou mais difícil a acomodação da nova sociedade nacional a um conservadorismo de tipo burkeano. Na América Ibérica, o passado e a tradição tendiam a se confundir com o Antigo Regime colonial, com o qual se acabava de romper. Destituída a América de passado aproveitável, deixava de ser possível, mesmo ao mais empedernido dos conservadores, olhar politicamente para trás. Ao contrário da Europa continental, onde podiam eventualmente defender o Antigo Regime, na América independente o liberalismo era uma fatalidade. O destino dos novos países não passava pela evolução orgânica com seu passado, mas pela superação das antigas tradições tornadas sinônimas 
de domínio estrangeiro, ignorância, despotismo e corrupção. Construir um Estado nacional implicava elaborar uma Constituição, criar ministérios, preparar uma burocracia, organizar exércitos etc. Em outras palavras, se os conservadores franceses podiam se dar ao luxo de ser reacionários, os ibero-americanos tinham de admitir a necessidade da modernização e do progresso (Lynch, 2008; Ricupero, 2010). Em um ambiente como esse, a versão burkeana do conservadorismo não poderia se tornar hegemônica, cedendo o passo àquela de ascendência reformista ilustrada, devidamente constitucionalizada, no Brasil de 1824, pela absorção do projeto dos desventurados monarquianos franceses de 1789 (Lynch, 2005). Isso não quer dizer que argumentos burkeanos não tenham sido mobilizados. Um número significativo de estadistas a eles recorreria para combater o espírito de inovação dos radicais e defender o gradualismo.

O mais significativo deles foi Bernardo Pereira de Vasconcelos (1795-1850), fundador do Partido Conservador, que, na qualidade de artífice do movimento denominado "Regresso", forjou, na década de 1830, um modelo político que erradicou as guerras civis e logrou pôr, afinal, o Estado nacional brasileiro de é $^{8}$. Seu contato com a obra de Burke parece ter se dado por intermédio dos Extratos publicados pelo Visconde de Cairu (ASI, 15/5/1844). Mas o senador mineiro também bebera argumentos "conservadores" em outros autores aparentados, como David Hume e Alexander Hamilton, nos quais recolheu argumentos favoráveis à centralização e que não podiam ser acusados de absolutistas, como ele o vinha sendo, por parte de seus adversários ${ }^{9}$.

8 Gigante intelectual, na definição de Nabuco, sustentáculo da Monarquia representativa, teórico do liberalismo conservador em política e economia, construtor de instituições, mas também avesso à democracia, à igualdade social e insensível à sorte dos escravos, tudo isso foi Vasconcelos. Admirado, temido e odiado, não deixou ninguém indiferente à sua passagem (Carvalho, 1999, p. 34) .

9 "Quando a minha cabeça estava cheia de todas as antigualhas, quando ela era dominada pelas ideias da Revolução Francesa, ninguém me chamava inimigo da 
Foram tais leituras que forneceram a Vasconcelos o embasamento teórico para recusar o cosmopolitismo liberal e abraçar uma concepção prudencial de política: "Em política e moral, não há princípios absolutos” (ASI, 25/5/1839). A invariabilidade supunha uma concepção da vida social orientada por princípios constantes e lógicos, quando as ciências políticas e morais, na verdade, ainda relevavam do domínio do experimental (ASI, 28/5/1839). A mudança de orientação político-ideológica, do liberalismo para o conservadorismo, não importava frouxidão de princípios: "Tudo muda em torno do homem, e que por isso não é de estranhar que ele também modifique suas ideias. É exigir muito da humanidade, impor-lhe a obrigação de pensar sempre do mesmo modo e não modificar os seus pensamentos" (ASI, 22/7/1839). Um estadista deveria ser apreciado por sua capacidade de modificar seus princípios quando aconselhado pela observação, pelo estudo e pela experiência: "Os perigos da sociedade 332 variam; o vento das tempestades nem sempre é o mesmo: como há de o político, cego e imutável, servir no seu país?” (Vasconcelos, 1999, p. 26). A concepção de política como uma ciência lógica, virtuosa, principista e invariável era rejeitada por seus péssimos resultados:

A rígida virtude de alguns homens de moral e a lógica que se apoderou de suas cabeças políticas foram as causas que mais influíram nas grandes catástrofes da França durante o reinado da Convenção. O célebre Burke, de que nos deu larga medida o Sr. Visconde de Cairu, e que por isso ninguém tachara de partidista e exaltado, ou de infenso à Monarquia, atribuía todos os erros, todos os absurdos, todos os atentados cometidos na França revolucionária ao predomínio que na política obteve a lógica. Robespierre

liberdade e da ordem, todos me aplaudiam; agora, que eu tenho desempoeirado a minha cabeça (e com que espanador?! Com o espanador de Hamilton e de outros), já não sou homem livre, sou um escravo" (ASI, 1/7/1840). 
e outros membros da Montanha não eram muito lógicos? (ASI, 15/5/1844).

A adoção dessa concepção antes prudencial do que ideológica de política levava Vasconcelos a se guiar, no plano prático, por um espírito de transação que se exprimia tanto no plano dos princípios quanto no da gestão pública. O espírito de transação levava à premência de harmonizar os princípios absolutos e abstratos da filosofia política "universal", conhecidos pelos livros que chegavam da Europa, com as circunstâncias particulares e concretas da realidade brasileira, conhecidas pela experiência local. O desafio do Brasil passava por resolver os problemas decorrentes da assimilação de diversas doutrinas e institutos jurídicos ingleses e norte-americanos, promovida nos anos anteriores pelos liberais. Calcada na crença de uma universalidade cultural e de uma relativa sincronia entre centro e periferia, aquela transposição provocara a erosão da autoridade pública e, como efeitos colaterais, a anarquia e guerra civil (Lynch, 2015). Era esse "progresso" precipitado que cumpria corrigir, conciliando as instituições de caráter universalista com os imperativos de fortalecimento da autoridade exigidos pelas nossas circunstâncias (ASI, 23/5/1844).

Resistir ao cosmopolitismo implicava reconhecer que o Brasil ainda não estava em condições de incorporar acriticamente instituições liberais de origem inglesa ou norte-americana: "A legislação de um país não pode ser transportada para outro, senão em circunstâncias raríssimas" (ASI, 3/7/1840). Os brasileiros não deveriam "imitar ou plagiar os ingleses; devemos estudar o nosso país, as nossas circunstâncias, e aplicarmos o remédio que elas reclamarem" (ASI, 19/7/1840). Haja vista que "a ideia do mundo não é a do movimento, e melhor lhe pode caber a denominação de ideia de resistência” (ASI, 6/7/1841), somente deveriam ser promovidas reformas políticas e sociais quan- 
do se chegasse "ao verdadeiro conhecimento dos verdadeiros interesses do país” (Vasconcelos, 1999, p. 253). Por isso, "convinha meditar as medidas que se propunham; se continham ou não um verdadeiro progresso, que fizesse cessar os sofrimentos e trouxesse ao país um melhoramento real" (Vasconcelos, 1999, p. 238).

O que se pode dizer, a esta altura, é que o propalado conservadorismo de Vasconcelos não passava por uma defesa do passado colonial, mas por uma proposta mais centralizadora e monárquica de Estado (Lynch, 2015, p. 331). A autoridade de Burke era invocada principalmente para brecar o cosmopolitismo liberal e as inovações político-institucionais inspiradas na Inglaterra e nos Estados Unidos, responsabilizadas pela incapacidade de debelar as guerras civis que destroçavam o Brasil. As circunstâncias atravessadas pelo país naquela etapa impunham excepcioná-lo do universalismo liberal e aplicar-lhe temporariamente os 334 remédios que dariam origem ao modelo político do Regresso, estatista, centralista e interventor ${ }^{10}$. A posição "particularista” de Vasconcelos, justificando a construção de um Estado forte, unitário e regulador, deu o tom do conservadorismo que vigoraria durante a primeira metade do reinado de Dom Pedro II, graças à sua ação e de outros estadistas conservadores, como Eusébio de Queirós, o Visconde de Uruguai e o Marquês de São Vicente ${ }^{11}$.

\footnotetext{
${ }^{10}$ Desfazendo parte das reformas anteriores, esse modelo restabeleceu o primado da União sobre as províncias, por meio da centralização efetuada pela lei de interpretação do Ato Adicional e pela reforma do Código de Processo Criminal; pela ascendência do gabinete sobre o Parlamento, por meio de um governo parlamentar tutelado; e, por fim, pela tutela da Coroa sobre o gabinete, pelo restabelecimento do Conselho de Estado.

${ }^{11}$ A principal autoridade europeia invocada pelos conservadores até a década de 1860 seria François Guizot, chefe do conservadorismo liberal francês, que aceitava o lado liberal da Revolução Francesa e justificava o fortalecimento do Estado na época moderna através de uma filosofia da história como civilização, que partia da desagregação da sociedade europeia com a dissolução do Império Romano e com as invasões bárbaras - representantes do "domínio privado" sobre a vida pública até a recuperação da via pública com a ascensão das cidades, da classe burguesa e
} 


\section{Crítica do conservadorismo estatista e defesa da sociedade escravista: o Burke tory de José de Alencar}

O conservadorismo de viés estatista prevaleceu de modo mais ou menos incontestado até a década de 1860. Generalizou-se então a sensação de que, consolidado o Estado, chegara a hora de substituir o modelo autoritário regressista por outro, mais canonicamente liberal. Tratava-se, numa palavra, de remover a herança do reformismo ilustrado. Semelhante tarefa foi tomada a peito por liberais como Tavares Bastos, cujas obras advogavam o liberalismo econômico, o imigrantismo, o parlamentarismo e o federalismo. Embora o movimento não passasse sem contestação pelos conservadores, o partido àquela altura já começava a ser arrastado pelo movimento de liberalização. A sensação de aceleração do tempo histórico encorajava cada segmento do espectro político-partidário a dar um passo adiante no caminho do "progresso" e da "democracia". A geração mais nova dos conservadores também se mostrava ansiosa por uma versão moderna de seu ideário, na forma de um conservadorismo liberal mais próximo dos tories britânicos e desvinculado do estatismo de Vasconcelos e do Visconde de Uruguai.

O mais expressivo intelectual do movimento de renovação conservadora foi o escritor e deputado cearense José Martiniano de Alencar (1829-1877). Crítico da francofilia das gerações anteriores, seu modelo de governo representativo era a Inglaterra. Se os próprios franceses citavam os ingleses, perguntava-se, "seremos nós, ainda na infância deste sistema, que poderemos considerar inútil e pretensioso instruir-nos nos exemplos fecundos da história parlamentar de países cultos?" (Alencar, 1979, p. 211). Ele provavelmente imaginava para si um papel semelhante àquele desempenhado por Benjamin Disraeli junto ao Partido Conservador

com a constituição dos Estados nacionais. O principal receptor de Guizot no Brasil foi Visconde de Uruguai (Carvalho, 1999; Ferreira, 1999; Coser, 2008). 
do Reino Unido. O futuro Conde de Beaconsfield - ficcionista, como Alencar - também havia sido um outsider nas fileiras aristocráticas do partido e se propusera a recuperá-lo do abatimento em que mergulhara desde que Peel o dilacerara, na década de 1840, ao propor reformas julgadas liberais pela porção mais "emperrada" do partido (notadamente, a revogação da lei que protegia o trigo produzido nas terras da aristocracia). Desde então, Disraeli vinha reorganizando a agremiação, adaptando-a às necessidades da época e disciplinando-a na tradicional defesa dos interesses da aristocracia rural (Watts, 2002a, pp. 79-90). José de Alencar ambicionava exercer idêntico papel de "educador" a respeito do Partido Conservador brasileiro, que ele julgava igualmente abatido pela prolongada prática de governos de coalizão ("conciliação") desde a década de 1850. Os conservadores brasileiros deveriam seguir os passos de seus homólogos britânicos em matéria de organização, fundan336 do uma união conservadora que estabelecesse seções em cada vila e cidade do Brasil e contivesse em seu programa escrito seus três princípios cardeais: o "respeito inviolável à Constituição, no estado atual das luzes"; "a independência prática dos poderes, atualmente aniquilada pela onipotência e degeneração do Executivo; quanto aos direitos civis, a realidade das garantias individuais, burladas pela viciosa organização da judicatura" (apud Magalhães Jr., 1977, p. 203).

Mas não bastava a reestruturação administrativa. Cumpria, sobretudo, reestruturar a ideologia do partido, e a continuidade de práticas que lhe pareciam reminiscências do Antigo Regime. Alencar (2009, p. 282) entendia a civilização como um processo de superação lenta e orgânica dos preconceitos do passado em direção a formas mais livres e justas de vida individual e coletiva. Entretanto, ele não fazia uma leitura do processo de maneira a detratar o passado; ao contrário, sua visão historicista romântica do processo civilizador, tributária de Burke, Chateaubriand e Savigny, o levava a crer que ele só 
se desdobrava adequadamente quando respeitador dos costumes: "A superstição do futuro me parece tão perigosa como a superstição do passado [...]. Consiste a verdadeira religião do progresso na crença do presente, fortalecida pelo respeito às tradições, desenvolvida pelas aspirações a maior destino" (Alencar, 1979, p. 283). Alencar não ignorava a condição atrasada e periférica do Brasil, mas entendia que esse fato não o apequenava nem o tornava menos estimável. A história, que era mestra da vida, mostrava que todos os países civilizados haviam, no passado, convivido com instituições úteis que, com o tempo, acabaram obsoletas e descartadas como bárbaras. Por isso, mesmo elas mereciam respeito: "Toda a lei é justa, útil, moral, quando realiza um melhoramento na sociedade e apresenta uma nova situação, embora imperfeita, da humanidade" (Alencar, 2009, p. 284). As reformas deveriam ser encaminhadas com prudência: "É necessário condescender às vezes com os prejuízos populares quando muito radicados, mas para corrigi-los, para destruí-los com prudência” (Alencar, 1979 , p. 594). Numa crítica ao materialismo anglo-saxônico dos liberais, Alencar fazia a defesa do ideal de latinidade católica romana, herdado da colonização ibérica:

A grandeza moral deste Império é obra de Deus. A exuberância do solo, a força criadora do clima, hão de fazêlo opulento infalivelmente. Do que mais necessitamos é da grandeza moral das virtudes que ornam a juventude dos povos; e já mareamos nós, império de ontem, nos vícios das nações decrépitas (Alencar, 1979, pp. 324-25).

Mas o liberalismo não era o único alvo de Alencar. Ele também atacava o conservadorismo estatista de seu próprio partido. Criticando a razão de Estado que orientava a política brasileira, ele advogava que a publicidade era a primeira garantia de uma administração "sisuda e moralizada". A classe política não poderia ser composta de burocratas, nem ser diri- 
gida pela Coroa; ela deveria ser integrada por profissionais liberais capazes de esclarecer e conduzir o país pela imprensa e pela tribuna. Era a opinião pública, e não a Coroa, o tribunal supremo da política (Alencar, 1979, p. 267). O estatismo era deplorado pelo aumento da máquina pública, por ele julgado um dos maiores fatores da degeneração do regime no Brasil (p. 117). A política não se assentaria em bases autenticamente representativas enquanto os partidos não se enraizassem na sociedade civil. Um autêntico sistema partidário caracterizava-se por uma "uma luta fecunda que, pondo em movimento as forças vitais do país, trouxesse o seu desenvolvimento e a sua prosperidade" (p. 241). Precisamente como os tories liderados por Disraeli, Alencar pretendia que o Partido Conservador se apoiasse, não na burocracia, mas na aristocracia rural, porque como dizia Burke - "a base mais sólida e firme de um bom governo é o solo” (p. 340). Já o Partido Liberal deveria 338 amparar-se nas classes comerciais e industriais. Assim, ambas as agremiações desempenhariam papéis definidos. Mas essa regeneração do sistema exigia ainda uma reforma eleitoral e a descentralização administrativa como remédio à "absorção do Poder Executivo, que se vai manifestando de uma maneira bastante nociva” (Alencar, 1979, p. 117). Os assuntos locais deveriam ficar por conta das localidades, a fim de que a grande política, a dos princípios, da alta administração, prevalecesse na esfera nacional.

A causa mais célebre em que Alencar empenhou seu conservadorismo renovado foi na oposição ao projeto de lei de liberdade do ventre escravo. Ele havia sido encomendado pela Coroa ao Marquês de São Vicente, jurista da ala burocrática ou reformista do Partido Conservador, durante a Guerra do Paraguai, com o apoio dos chefes liberais. Na ocasião (1866-1867), Alencar alegara que a escravidão estava profundamente enraizada na sociedade e não deveria ser extinta por medidas impostas pelo Estado. A escravidão civi- 
lizara a América porque, por força da necessidade, havia sido a única forma de povoar o continente nos primeiros séculos. Considerada legítima, ela fora paulatinamente deixando de sê-lo por força da evolução dos costumes. Nesse quadro, os conservadores deveriam deixar "que o problema da escravidão se resolvesse por si, por uma transformação lenta e pela revolução social dos costumes" (Alencar, 1979, pp. 238-39). A sociedade brasileira amolecera a rigidez daquele regime, integrando-o na teia mais ampla da solidariedade social. A interferência do Estado reverteria aquele movimento benfazejo, atentando contra os direitos dos senhores, incitando o ódio entre as raças e arruinando a economia. A intromissão do governo prejudicaria os próprios escravos, que não estavam preparados para a liberdade e acabariam na miséria e no alcoolismo.

Quando a guerra terminou, o Imperador incumbiu membros da ala burocrática ou cortesã do Partido Conservador o Marquês de São Vicente e, em seguida, o Visconde do Rio Branco - de aprovarem a passagem da lei pela Assembleia do Império. A ala do partido vinculada à propriedade rural, chefiada pelo Visconde de Itaboraí e seu sobrinho, o conselheiro Paulino Soares de Sousa, rompeu com o governo e se aliou aos liberais para denunciar o suposto absolutismo da Coroa. Aos olhos de Alencar, o emprego do conservadorismo estatista, típico do reformismo ilustrado, renovava entre nós o processo nefasto que levara o Partido Conservador britânico a dilacerar-se na década de 1840. Rio Branco representava aqui o papel de Peel, e o projeto de lei do ventre livre, aquele que lá revogara as leis de proteção ao trigo. Mais uma vez, tratava-se de empregar o Partido Conservador para a aprovação de leis liberais contra os interesses da grande propriedade agrícola, que ele, ao contrário, deveria defender.

Na Câmara dos Deputados, embora o chefe da oposição fosse o conselheiro Paulino, o cérebro intelectual era Alencar. Uma vez que o modelo político regressista permitia a 
imposição de medidas como aquelas pela Coroa, era preciso que os oposicionistas não poupassem o Imperador. De fato, Alencar acusou Dom Pedro II de, com sua iniciativa, subverter os princípios do governo representativo: “Aqui, longe de se resistir ao Rei, é de cima que vem o impulso. A opinião não exercia pressão alguma sobre o governo. Donde ela recebeu essa pressão? Do alto" (Alencar, 1979, p. 203). Diferentemente do que afirmavam os defensores da emancipação, a escravidão seria uma instituição com grande apoio social, que só passara a ser questionada a partir da interferência da Coroa (Ricupero, 2004, p. 188). A medida também perturbava o sistema partidário: já não se via a luta regular entre progressistas e conservadores, mas "a luta do poder com a nação"; "a luta do elemento oficial contra os interesses máximos do país” (Alencar, 1979, p. 225). Aquilo de que ao país carecia não era de abolição, mas de acabar com a tutela do governo sobre a sociedade civil: "Que 340 ideia faz o governo da nação brasileira? Pensa que não somos um povo, mas um rebanho que se dirige com um aceno?" (p. 230). Cabia ao Partido Conservador conter o poder pessoal do Imperador e resguardar os interesses da lavoura pela restauração da "verdade do governo parlamentar" (p. 192).

Em síntese, a tentativa de aclimatação do conservadorismo tory por Alencar deve ser compreendida no contexto de renovação do partido na década de 1860. Alencar foi o primeiro a propor a substituição do estatismo intervencionista por uma espécie de torismo agrário. Não se tratava mais de fortalecer o Estado para garantir a ordem social, mas de privá-lo de sua capacidade de reformá-la. Ele julgava que a nação já se encontrava constituída, com seus traços próprios, originais, autênticos, e que o imperativo da modernização não poderia ser de tal ordem que a descaracterizasse. A vida no campo, com sua atividade agrícola escravista e suas hierarquias naturais, dava o tom da autêntica sociedade brasileira, que necessitava ser resguardada contra os estrangeirismos da 
Corte (Alencar, 1993). Daí o conteúdo fortemente culturalista do conservadorismo renovado de Alencar.

Mas nem tudo era reprodução do torismo inglês. A tentativa de aclimatar o conservadorismo britânico exigia uma reforma do modelo político-institucional que era tão subversiva das tradições brasileiras de reforma ilustrada quanto aquela proposta pelos liberais. O emprego da prerrogativa da Coroa para promover reformas contrárias aos interesses da aristocracia rural levava Alencar a um extremo impensável no torismo original, que passava pela violenta desaprovação da conduta do próprio monarca. Reiterado na década de 1880 contra a Coroa, novamente acusada de pressionar a passagem de novas leis abolicionistas, esse traço politicamente subversivo do novo conservadorismo levaria um liberal como Joaquim Nabuco a confessar-se, em 1885, espantado com "a facilidade com que o conservador neste país se inclina para o republicano”. Ao seu juízo, o espírito conservador no Brasil se tornara "mais propenso à fronda, à rebelião, ao pronunciamiento, do que o espírito liberal" (Nabuco, 1999, p. 84; grifo do autor).

\section{Crítica do autoritarismo científico e defesa da herança liberal monárquica: o Burke whig de Rui Barbosa e Joaquim Nabuco}

Na segunda metade do século XIX, Burke começou a deixar de ser monopólio dos conservadores brasileiros. Assim como eles estavam atentos à renovação do conservadorismo britânico promovida por Disraeli, a nova geração de liberais seguia de perto o movimento simétrico operado por William Gladstone no Partido Liberal daquele país. Em 1867 foi publicada a famosa biografia escrita por John Morley, cujas credenciais de liberal eram inegáveis, e que lhe serviu de principal referência pelos cinquenta anos seguintes, ao longo de suas sucessivas reedições $(1879,1888,1905)^{12}$.

${ }^{12}$ Morley foi o mais conhecido dos expositores do pensamento de Burke no final do 
Em 1870, a instauração da Terceira República na França terminou de anglicizar a orientação intelectual dos partidos monárquicos, suscitando maior interesse pela história constitucional inglesa - ela mesma, toda de extração whig. Nas três primeiras décadas do Império, aquela influência se fizera sentir intermediada pela experiência da Restauração e da Monarquia de Julho. Os autores citados eram os franceses, e os ingleses eram lidos por traduções francesas. A partir da década de 1860, a mediação francesa esmoreceu e as referências às fontes primárias inglesas tornaram-se usuais. Em 1874 saiu a primeira seleção de obras de Burke, permitindo ao público descobrir o caráter multifacetado de sua atuação - em especial, o seu lado mais caracteristicamente whig e, portanto, liberal, anterior às Reflexões sobre a Revolução em França (Maciag, 2013, p. 116). Estes e outros fatos, que não podem ser aqui descritos com o detalhe que merecem, permitiram aos jovens liberais brasileiros como 342 Rui Barbosa (1849-1923) e Joaquim Nabuco (1849-1910) considerarem Burke de modo mais complexo, no conjunto de sua atuação e tempo.

No início de sua carreira política, Rui Barbosa era um liberal radical cuja orientação seguia de perto aquela de John Stuart Mill, "o maior pensador político do nosso tempo, o autor dos melhores livros modernos sobre a democracia e a liberdade, o sábio bem temperado em suas opiniões" (Barbosa, 1966, p. 22). Mas, desde pelo menos seu tempo de terceiranista da Faculdade de Direito, seus escritos já abundavam em referências ao publicista irlandês. O baiano recorreu ao conceito de partidos do Discurso aos eleitores de Bristol para criticar os conservadores (Barbosa, 1988, p. 16); pinçou uma passagem do Impeachment de William Hastings em seu elogio fúnebre de José Bonifácio, o

século XIX e o que mais influência teve em sua interpretação sobre os autores da centúria seguinte (Claeys, 2017). Em 1936, Laski (1973, p. 142) escrevia: "Sobre Burke, o melhor trabalho ainda é o de Lorde Morley, Edmund Burke, an historical criticism". 
Moço, referindo-se a Burke como "o maior dos modernos" (Barbosa, 1962, p. 324); mencionando ainda o "gênio de Burke" em matéria monetária (Barbosa, 1965, p. 46). Rui o considerava uma espécie de Stuart Mill do século XVIII, cuja obra era de grande valia em um país atrasado como o Brasil, cujos problemas políticos seriam semelhantes àqueles experimentados pela Grã-Bretanha um século antes. Por isso, desde muito cedo, Rui mobilizou sua autoridade de chefe "whig" para condenar o suposto "poder pessoal" da Monarquia brasileira, atacando Dom Pedro II como Burke atacara Jorge III à sua época:

Advirtam em que, há mais de um século, desde 1770, na Inglaterra, o grande estadista que a filosofia política venera como talvez o maior dos talentos que a têm interpretado; o eminente liberal que, nos piores dias de Jorge III, deixou eternizada, num estilo indelevelmente lapidar, a justificação dos descontentamentos do povo contra o vício canceroso do aulicismo introduzido, sob a conjuração do rei com os amigos do rei, nos órgãos essenciais da vida constitucional; o ilustre Burke, no seu célebre panfleto, cuja atualidade, sob a Monarquia constitucional, tantas vezes, infelizmente, e em tantos países, se tem reproduzido, consignava já a existência de uma teoria, de uma praxe, de um sistema de governo que, "sem contravir à letra de lei alguma, opera, todavia, contra o espírito de todo o direito constitucional” (Barbosa, 1943, p. 125).

No último ano do Império (1889), Rui afirmaria que Burke compusera, juntamente com Charles Fox e William Pitt, "no mundo daquela época extraordinária, as três grandes altitudes da sabedoria política"; ele teria sido "a mais sublime cabeça política de que se desvanece a Inglaterra". Sendo 
[...] o pugnador formidável da Revolução Francesa, o mais irreconciliável inimigo da democracia revolucionária, não hesitou, contudo, em ferir na fronte a realeza, apontando à indignação pública o sistema de rapinagem, de que o país era vítima sob os auspícios do trono, e que, perdendo a América, desengastara da Coroa da Inglaterra a sua mais preciosa gema (Barbosa, 1947, p. 324).

Já aqui se pode intuir em que medida Rui se valia retoricamente da fama de adversário da demagogia desfrutada por "Burke, o imortal Burke" (Barbosa, 1948, p. 160): ela lhe permitia atacar as práticas que ele julgava autoritárias, não na condição de radical, mas de verdadeiro amigo do regime, que queria reformado para que pudesse sobreviver. Tal não o impediu de aderir ao novo regime republicano, servindo como um dos principais ministros do Governo Provisório e encarregando-se do anteprojeto da nova Cons344 tituição (Lynch, 2014, pp. 219-23).

Pouco depois, em 1893, quando o governo do marechal Floriano promoveu a derrubada dos governadores dos estados e passou a governar por meio de estados de sítio inconstitucionais, apareceu nova oportunidade para que Rui invocasse Burke. A defesa dos atos de exceção era feita pelos florianistas a partir de um discurso autoritário, jacobino e positivista, que justificava a suspensão da Constituição em nome da salvação pública (Lynch, 2012a, p. 161-62). $\mathrm{Na}$ medida em que se tratava de defender o "princípio da autoridade", os assim chamados jacobinos reivindicavam a condição de conservadores da República ${ }^{13}$. Foi nesse contexto

\footnotetext{
${ }^{13}$ Assim, por exemplo, reagiu o deputado florianista Alcindo Guanabara, quando acusado de conservador por um membro da oposição liberal: "Sem a sombra de uma dúvida; sem a mínima hesitação! Sim, conservador, como o fui nos primeiros anos da minha vida, como o sou na idade madura e, já agora, como espero em Deus que serei até a morte: conservador por índole, conservador por tradição que não me deslustra e que eu não renego; conservador por educação, conservador por temperamento; isto é, um homem político e pessoalmente votado à defesa
} 
que Rui Barbosa (1956, p. 341) voltou a invocar Burke, “o maior gênio político de uma idade de gênios". O autor invocado não era mais, todavia, o ardente liberal dos Present discontents, por Rui mobilizado na juventude, mas o conservador das Reflexões sobre a Revolução em França, que denunciara o jacobinismo como

[...] a confraria feroz que impôs à revolução a ditadura da ignorância, da malvadez e da improbidade, que matou a república, preparando a prostituição do diretório e o absolutismo do Império, e que ainda hoje assombra o mundo por seus crimes, por sua corrupção e por sua imbecilidade (Barbosa, 1956, p. 31).

Contra os radicais do jacobinismo florianista, Rui avocou também para si a qualidade de conservador, nesta qualidade, ele propôs a criação de um "partido conservador republicano" capaz de resguardar os "interesses conservadores, e considerar o abismo, que separa demagogos de democratas, e jacobinos de republicanos. O espírito jacobino é a negação do verdadeiro espírito republicano" (Barbosa, 1956, p. 32). Claro está que o "conservadorismo" de Rui pouco ou nada tinha a ver com aquele de seus adversários. Se os florianistas entendiam por conservadorismo a defesa do "princípio da ordem e da autoridade", Rui interpretava aquele epíteto como sinônimo de defesa do "princípio da liberdade" consagrado na Constituição, aniquilado pelos atos de exceção florianistas. Da mesma forma, contra a defesa jacobina e positivista da República, Rui opôs o sereno liberalismo anglo-americano: "Os Estados Unidos são apenas um ramo da Inglaterra, a grande árvore da liberdade no mundo moderno" (Barbosa, 1960, p. 876). Era à sua doutrina

da autoridade, da lei e da ordem, do regular exercício dos poderes públicos, não concebendo o progresso senão como necessária consequência desses elementos capitais na sociedade" (ACD, 30/6/1894). 
e espírito whig de moderação e tolerância que se deveria recorrer para interpretar as instituições da República - e não ao funesto e sempre autoritário radicalismo francês: "Não estive ontem, não estou hoje, não estarei amanhã com os violentos [...]. 'Defendi sempre a liberdade dos outros', dizia Burke. Esta deveria ser a divisa de todos os homens de Estado" (Barbosa, 1956, p. 329). Em outras palavras, se por "conservador" os florianistas entendiam "defesa de autoridade", por aquela expressão Rui muito liberalmente considerava, ao contrário, a defesa da liberdade.

Mas, depois da derrubada do Império, o principal anglófilo a mobilizar Burke para combater o radicalismo jacobino de fundo "científico" foi mesmo Joaquim Nabuco. $\mathrm{O}$ antigo chefe do movimento abolicionista recusou-se a aderir ao novo regime na crença de que a Monarquia parlamentar era a melhor forma de governo - a mais republicana, a mais democrática e a mais liberal - possível em uma 346 sociedade atrasada como a brasileira de seu tempo. E, ao seu juízo, os descalabros da primeira década do novo regime lhe pareciam comprovar a tese.

Nabuco, pensando a partir de liberais como Stuart Mill e Tocqueville, acreditava que as nações evoluíam politicamente através de um longo processo de três etapas, que começava pela construção conservadora e autoritária do Estado nacional ("momento tory"), continuava pela sua posterior conversão em Estado de direito pelos liberais ("momento whig"), para, afinal, democratizar-se pela incorporação cívica da maioria (Lynch, 2012b). No caso brasileiro, vencidas as duas primeiras etapas pelo esforço sucessivo dos conservadores (do tempo do "Regresso") e dos liberais monárquicos (a partir da Conciliação), Nabuco acreditava que o Império abrira as portas do processo de democratização depois da Abolição. Por isso, terminara a 15 de novembro de 1889 abatido por um golpe militar, orquestrado pelo oportunismo republicano coligado aos setores mais retró- 
grados da sociedade brasileira, vinculados à aristocracia agrária escravista defendida pelo conservadorismo renovado fundado por Alencar. Desde então, a agenda nacional brasileira viria sofrendo seguidos retrocessos. À interrupção da democratização imposta pelo golpe republicano se seguiria a destruição do Estado de direito pelas presidências dos marechais Deodoro e Floriano, marcadas por estados de sítio, intervenções federais e perseguições à oposição, que era presa, desterrada e fuzilada, no melhor estilo das repúblicas hispânicas. Guerras civis como a Revolta da Armada e a Revolução Federalista prenunciavam o último ato: o esfacelamento do Estado nacional e a fragmentação do país.

Em suma, Nabuco cria que a República estava destruindo em pouco tempo a delicada obra de construção do Brasil, que custara o esforço de gerações de conservadores e liberais leais à Monarquia. Por isso, em obras como Balmaceda e Um estadista do Império, Nabuco recorreu a Burke para apresentar o reformismo liberal do Império como um modelo de orientação política a ser emulado. Embora tivesse nas mãos a biografia deixada por John Morley, o autor de Minha formação esteve longe de segui-la de modo servil. Liberal gladstoneano, comprometido com a democratização do sistema político e social britânico, Morley não podia deixar de criticar as prevenções antidemocráticas de Burke reveladas depois de 1790 . Esta era uma posição que o próprio Nabuco teria endossado ao tempo da Monarquia, ele mesmo admirador de Gladstone. A percepção, porém, de que as circunstâncias da política brasileira se haviam alterado radicalmente, retrocedendo de forma dramática, o levou a descartar aquelas reservas e a adotar uma postura mais reverente à "sabedoria prática" da doutrina burkeana.

Assim, contra a autoritária "política científica" dos republicanos, responsável pelo terrorismo florianista, Nabuco escreveria em Balmaceda: "Certas leis existem em política que se podem chamar científicas, no sentido em que a 
economia política, a moral, a estatística, são ciências, mas a política em si mesma é uma arte tão prática como a conduta do homem na vida" (Nabuco, 1949a, p. 39). Um liberalismo moderado, tolerante e pluralista, era indispensável em um ambiente turbulento como o latino-americano, cuja invertebrada sociedade ainda possuía uma cultura política autoritária. As reformas eram indispensáveis, mas elas deveriam respeitar as institucionalidades que tornavam a liberdade historicamente possível em cada país: "O reformador em geral detém-se diante do obstáculo; dá longas voltas para não atropelar nenhum direito; respeita, como relíquias do passado, tudo o que não é indispensável alterar; inspira-se na ideia de identidade, de permanência" (Nabuco, 1949a, p. 39). Essa predileção pelo reformismo whig, Nabuco denominava atitude conservadora: "A tradição toda da palavra refor$m a$, tomada primeiro à mais tranquila de todas as histórias, a dos mosteiros, é conservadora, e encerra em si dois gran348 des sentimentos: o de veneração e o de perfeição" (Nabuco, 1949a, p. 39). Essa nobre ciência da política, liberal e tolerante, era o atributo típico de sociedades civilizadas:

O que distingue as sociedades e as pessoas cultas é que nas grandes divergências de boa-fé, que só se podem resolver pela ruína de ambas as partes se lutarem, elas sujeitam-se a um laudo, ou, de alguma forma, transigem" (Nabuco, 1949, p. 124).

Como Burke, o whig Nabuco acreditava que

[...] o espírito essencial da democracia poderia ser mais bem servido quando a vontade genuína do povo fosse mediada por uma aristocracia natural de homens "sábios", "judiciosos", "sóbrios", "decentes", "suaves e piedosos". O propósito de semelhante elite não era impor sua própria vontade, mas implementar e orientar os humores do povo 
por caminhos que fossem responsáveis e consistentes com as tradições existentes (Maciag, 2013, p. 20).

O radicalismo intolerante em que se baseavam os positivistas para dar livre curso ao seu "espírito de inovação" baseava-se em uma concepção falsamente "científica" de política, extraída de um idealismo abstrato e sem qualquer fundamento na experiência e na história:

Ao que parece, [o radical] é um espírito amigo da novidade, ao qual nunca ocorreu a frase de Burke: "Há uma sorte de presunção contra a novidade, tirada da observação profunda da natureza humana e dos negócios humanos”. A versatilidade desses espíritos alvissareiros não é um simples vício intelectual, ou uma doença atávica do espírito. [...] O homem torna-se uma espécie de títere de biblioteca; deixa de pensar por si, de contar consigo; é o eterno sugestionado, em cujo cérebro se sucedem rapidamente em combinações extravagantes as quimeras alheias, os sistemas antípodas; não é mais, em sentido algum, uma individualidade, é um feixe de incompatíveis (Nabuco, 1949a, p. 122).

Em Um estadista do Império (de 1897), Nabuco aplicaria à história do Segundo Reinado a teoria whig do desenvolvimento político adaptada à América Latina, por ele delineada em Balmaceda. Do ponto de vista ideológico, a monumental obra em três volumes era um canto elegíaco ao liberalismo monárquico, reformista e moderado, de que a Conciliação e o Progressismo haviam sido os exemplos mais admiráveis, e do qual seu pai, o senador Nabuco de Araújo, teria sido o representante por excelência. Conservador na mocidade, liberal na velhice, o falecido chefe progressista era descrito como dotado de um temperamento whig, com o seu "espírito de autoridade, gradualmente penetrado de liberalismo, isto é, de tolerância e 
de equidade, mas equiparando sempre as aspirações e processos revolucionários à pura anarquia e subversão social" (Nabuco, 1997, p. 320). Sua caracterização ideológica seguia de perto aquela dos comentadores de Burke a respeito deste: um reformista utilitário, destituído de espírito de sistema, guiado por uma sensibilidade às circunstâncias políticas e sociais de seu tempo ${ }^{14}$. O senador Nabuco teria sido "um idealista prático, um espírito sempre com um grande objetivo diante de si, às vezes longínquo, difícil, complexo, mas procedendo em tudo com espírito positivo, legislando para a sociedade presente e procurando nela seus pontos de apoio e seus meios de ação" (Nabuco, 1997, p. 81). Nesta qualidade, seu liberalismo não se confundia nem com os conservadores, que, à direita, orientavam-se por um realismo puro e duro, lidando apenas com fatos (como o senador “saquarema” Eusébio de Queirós), nem com os radicais, que, à esquerda, deixavam-se arrastar por um idealismo vago e abstrato (como o senador "luzia" José Boni350 fácio, o Moço). No fim do livro, ao qualificar seu pai como "o guia mais seguro dos espíritos positivos, que aliam, como Burke, o liberalismo utilitário e o conservantismo histórico”, Nabuco (p. 1126) não fazia mais do que repetir, em toda a sua literalidade, a expressão empregada por Morley para designar o autor das Reflexões: "Burke's utilitarian liberalism and his historic conservatism” (1888, p. 137).

Como explicar esse vaivém por parte de liberais como Rui Barbosa e Joaquim Nabuco, entre o radicalismo e um aparente conservadorismo? Tratava-se de uma clara herança da cultura anglófila do Império, segundo a qual circunstâncias excepcionais autorizavam o estadista guiado pela prudência a passar de um polo a outro, sem deixar o terreno do libera$\operatorname{lismo}^{15}$. O precedente de Burke havia sido repetido na pró-

\footnotetext{
${ }^{14}$ Os comentadores de Burke à época, a começar pelo próprio Morley, percebiam a dimensão prática de seu reformismo e destacavam suas supostas afinidades com o utilitarismo de Bentham e Mill (Dwan, 2012, pp. 131 e 143; Maciag, 2013, p. 109).

15 Tratava-se de uma orientação compartilhada pelos próprios conservadores mo-
} 
pria Inglaterra por alguns de seus mais importantes estadistas, como Peel, Palmerston e Gladstone; no Brasil, depois do precedente de Vasconcelos, o mesmo se passara com chefes como Nabuco, Zacarias e Rio Branco. Era a partir do mesmo pressuposto que Joaquim Nabuco (1997, p. 128) explicava o ziguezague de seu pai (e, indiretamente, os próprios): "Os que o veem indicar o perigo de um lado e logo do lado oposto, julgam-no incoerente, mas é que a estrada corre entre precipícios e que ele olha à direita e à esquerda e não vê os abismos somente de uma margem". Para os estadistas da Monarquia brasileira, "passar de conservador a liberal, ou vice-versa, era apenas uma combinação diferente de moléculas dentro da mesma forma” (p. 1123).

O próprio Rui voltaria ao assunto na década de 1910 - agora na condição de líder da oposição liberal e defensor de reformas contra as oligarquias coligadas. Acusado, mais uma vez então, de radical por parte de um establishment autoproclamado "conservador" das instituições, o autor da Réplica teve ocasião de responder - à maneira burkeana que todo sistema político democrático dependia da convivência e da alternância entre os dois elementos liberais, o radical e o conservador: "Os dois princípios têm de se revezar e, até, de se auxiliar um ao outro, porque se completam e se suprem mutuamente" (Barbosa, 1984, p. 138). Entretanto, nas circunstâncias especificamente atravessadas pelo Brasil, tanto em 1889 quanto em 1916, as reformas exigidas pelos radicais visavam atender a demandas que, represadas,

derados da década de 1860, como os senadores Visconde do Rio Branco e Firmino Rodrigues da Silva. Este último o diria textualmente: "A ideia conservadora é destinada, como já ponderei, a manter ilesas as nossas instituições políticas. Ora, sendo elas de uma suma liberdade nacional, excelente forma de governo representativo, os conservadores políticos são liberais; e como os liberais prezam muito a liberdade, mas, segundo os princípios da Constituição, também são conservadores das mesmas instituições. Portanto, deve-se julgar que só não são liberais os conservadores do governo absoluto e conservadores liberais deste país, que forem republicanos" (ASI, 27/6/1874). 
poderiam destruir as instituições. Ajudavam assim a conservá-las, ao passo que a intransigência dos "conservadores" republicanos apressava a sua destruição. Nessas condições, explicava Rui, eram radicais liberais como ele os verdadeiros conservadores, e os conservadores, os autênticos revolucionários:

Não há nada mais ilusório do que o antagonismo, que, de ordinário, se supõe entre o conceito de preservação, reservado às ideias conservadoras, e o conceito de subversão, reservado às ideias radicais. Em última análise, entre as preferências conservadoras e as preferências radicais, toda a diferença consiste mais no grau do que na substância das coisas. Porque situações há em que a resistência conservadora conduz à revolução e, nesses casos, o preconceito da conservação redunda numa influência destruidora; assim como, pelo contrário, acontece haver conjunturas, nas quais a intervenção radical salva das revoluções, e, em casos tais, as soluções, presumidamente revolucionárias, do radicalismo, são as que exercem a verdadeira ação conservadora. A oportunidade é tudo (Barbosa, 1984, p. 138).

Como se vê, ao contrário do que sugerem Antonio Candido (2004) e Ângela Alonso (2009), o vaivém dos liberais brasileiros não era um expediente a que apelavam para encobrir seu "fundo conservador", mas um recurso tático autenticamente liberal, extraído da cultura política anglófila do Império, à qual se mantiveram fiéis sob a República. No auge de sua campanha em defesa da monarquia, Nabuco insistiria em sua caracterização liberal à inglesa: "Seria difícil colher-se de todo o meu pensamento um resquício de tendência conservadora" (Nabuco, 2004, p. 34). Sua repulsa pela República não decorria do caráter mais "adiantado" do novo regime, mas de seu caráter mais retrógrado: "O atual sistema é conservador. Não serve para um liberal como eu" (Nabuco, 
1949b, p. 126). Daí igualmente seu entusiasmo, quando embaixador nos Estados Unidos, pela presidência de Theodore Roosevelt, cujo reformismo progressista era orientado por uma sensibilidade burkeana afim à sua e que contrastava com as práticas autoritárias e oligárquicas da República brasileira (Maciag, 2013, pp. 122-42). Rui Barbosa também não deixaria, na qualidade de chefe do Partido Republicano Liberal, de recordar, no Senado, em 1913, a superioridade do liberalismo anglófilo do Império em matéria de pensamento progressista (Lynch, 2008). Diante da reação indignada dos republicanos conservadores liderados por Pinheiro Machado, Rui retrucaria de forma típica: "Quer Vossa Excelência comparar a República brasileira com a Monarquia inglesa?" (Barbosa, 1974, p. 412). Contra o cientificismo autoritário do novo regime, fosse ele jacobino ou oligárquico, Rui e Nabuco fariam sempre a defesa do liberalismo anglófilo herdado do Império, tanto na versão original inglesa, quanto na posterior, norte-americana.

A pesquisa sobre a recepção de Burke no Brasil examinou o modo por que argumentos desse autor foram assimilados por cinco intelectuais brasileiros, em diferentes momentos de nossa história: o de crise do Antigo Regime colonial (Visconde de Cairu); o de construção do Estado nacional (Bernardo Pereira de Vasconcelos); o da emancipação da sociedade civil (José de Alencar); e, por fim, o de instauração autoritária da República (Rui Barbosa e Joaquim Nabuco). Tudo indica não ter havido um único conservadorismo, mas vários, a que buscamos aludir aqui pelas denominações de reformismo ilustrado, depois conservadorismo estatal, conservadorismo culturalista, e, por fim, liberalismo conservador. Típico reformista ilustrado, Cairu queria modernizar a sociedade, ainda que aos bocadinhos, liberalizando a sua 
economia e abolindo a escravidão. Já Vasconcelos pretendia acabar com as guerras civis pela construção de um Estado unitário, marcado pela supremacia do Executivo e pela tutela da sociedade, que julgava inorgânica. Acreditava que a escravidão deveria permanecer enquanto não se arranjasse um meio de substituí-la. Alencar, por sua vez, valorizava as tradições nacionais brasileiras, que incluíam a vida no campo e o tipo de sociabilidade gerado pela escravidão. Para protegê-las, atacou vigorosamente as instituições políticas tradicionais, a começar pelo Imperador. Só um Estado enfraquecido pelo liberalismo poderia, pensava Alencar, conservar as hierarquias sociais. Mas também houve uma leitura whig de Burke por parte de membros destacados do movimento liberal reformista, que lutavam pela abolição da escravatura e pelo federalismo. No Império, Rui Barbosa valeu-se do jovem Burke para atacar o poder pessoal da Coroa; na República, recorreria ao velho para combater 354 o jacobinismo. Nabuco se valeria de Burke de modo mais largo e aprofundado, para fazer o elogio do liberalismo moderado como fórmula por excelência de reforma, apresentando o regime decaído como o arquétipo do Estado de direito possível na América Latina.

$\mathrm{O}$ artigo procurou esclarecer a lógica das diferentes recepções de Burke a partir das diferentes culturas políticas de cada país. Viu-se que, ao contrário do que se passara nos Estados Unidos, não havia na América ibérica tradição constitucional, mas uma versão colonial do Antigo Regime ibérico, com uma herança católica e absolutista, como na França. Mas, ao contrário do que nela se passara, a independência rompera com o passado e não tinha tradições nacionais às quais pudessem os próprios conservadores apelar. Além disso, a nova sociedade ibero-americana era julgada e condenada por seu inequívoco atraso, o que explicava a pregnância da ideologia do despotismo ilustrado. Acreditava-se que 
somente um Estado forte e esclarecido, apartado da sociedade atrasada, teria condições de promover sua modernização. Foi com essa cultura política que conservadores e liberais ibero-americanos tiverem de se haver depois da independência, para bem ou para o mal. Da herança ilustrada, resultaria o apreço por ideologias ambíguas, que embalavam a tradição em roupagens novas, como o positivismo. Difícil conservadorismo (Lynch, 2008; Ricupero, 2010). Em países cujo "passado" era antiliberal e católico, destituído de uma sociedade moderna triunfante, só seria possível recorrer ao Burke das Reflexões de modo seletivo, limitado o conservadorismo a absorver críticas ao radicalismo e o elogio da mudança incremental.

No conjunto da América ibérica, o caso brasileiro foi certamente singular. A independência sob o signo da Monarquia constitucional elevou a Constituição da Inglaterra à posição de seu modelo político central, com todos os seus consectários teóricos e doutrinários. Entretanto, as instituições monárquicas não eliminaram do Brasil os constrangimentos que existiam também nas repúblicas vizinhas, relativas à aclimatação e ao desenvolvimento de um conservadorismo de linha burkeana. Tanto aqui quanto lá, as elites se defrontaram com a tarefa de erigir um Estado nacional sobre um vastíssimo território desabitado, dotado de uma população dispersa, governada por caudilhos turbulentos e regida por códigos tradicionais de comportamento. A cultura ibérica, somada à consciência do atraso da sociedade nacional, facilitou a associação entre forma constitucional e prática ilustrada, como se percebeu pela reflexão do Visconde de Cairu. Isso explica também por que Vasconcelos e o Visconde de Uruguai tenham preferido reivindicar a autoridade dos doutrinários franceses como Guizot - liberais que, preocupados com a governabilidade pós-revolucionária, também não dispensavam um Estado forte e centralizado como fórmula de civilização nacional. É que a lógica 
do período pós-independência exigia antes um absolutismo estatista à maneira de Hobbes (Mattos, 1994) do que o conservadorismo defensivo de Burke.

Apenas quando o Estado brasileiro se consolidou, a sociedade civil se insinuou e a agenda reformista se impôs, foi possível a emergência de um conservadorismo mais típico, agrário e culturalista, de extração tory. Ainda assim, enfrentaram-se dificuldades. A valorização da sociedade tradicional, tal como herdada da colonização, afrontava a percepção da opinião pública urbana e cosmopolita, avessa ao mundo rural, analfabeto e escravista. Além disso, a defesa das tradições sociais no Brasil impunha o dever de combater a tradição política que, na forma do reformismo ilustrado, as ameaçava do alto do Trono. Em nações saídas de um continente novo, mas atrasado, a aclimatação de um conservadorismo como o burkeano seria sempre problemática.

Quanto aos liberais, representantes de uma época de afir356 mação da sociedade moderna contra os excessos do Estado, sua atitude conservadora não passou de uma posição tática imposta por circunstâncias excepcionais. Não era tanto um conservadorismo quanto um liberalismo conservador; um "reformista em um contexto de crise" (Trigueiro, 2017, p 53). Puderam, porém, ser fiéis, se não à versão tory, pelo menos à versão whig de Burke. Foram, assim, três diferentes linhagens que, plantadas pela cultura política anglófila do Império, frutificariam no pensamento político brasileiro do século XX. O conservadorismo estatista de Vasconcelos, de inspiração ilustrada, desaguaria em Oliveira Vianna; o culturalista de Alencar, defensor das tradições sociais ibéricas, em Gilberto Freyre; o liberalismo político de Rui e Nabuco, em Carlos Lacerda e Afonso Arinos de Melo Franco. Em todos eles, um único traço comum: o desejo de mudança sem subversão. Nessa qualidade, poderiam, em circunstâncias excepcionais (como em 1964), pôr de lado suas diferenças contra o radicalismo e a revolução. 
Para concluir, cumpre recordar aqui a conhecida hipótese aventada por Sérgio Buarque de Holanda, segundo a qual os conservadores imperiais nem teriam lido Burke nem sido conservadores de verdade, mas apenas "atrasados", isto é, personagens tradicionalistas e paroquiais refratários ao progresso do país ${ }^{16}$. As evidências aqui coligidas sugerem que também o ilustre autor de Do Império à República estava equivocado. A despeito da polissemia do conceito de conservadorismo exibida pelos autores ora estudados, é inegável que todos eles não apenas leram Burke, como se apropriaram de seu pensamento levando em conta tanto as diferenças entre a sociedade brasileira e a britânica, quanto as agendas de seus tempos. Revelaram assim a complexidade do conservadorismo brasileiro, dividido entre ilustrados e pragmáticos, tories e whigs, abolicionistas e escravistas, estatistas e liberais. Um conservadorismo caleidoscópico.

\section{Christian Edward Cyril Lynch}

é professor do Instituto de Estudos Sociais e Políticos da Universidade do Estado do Rio de Janeiro (IESP-UERJ) e da Universidade Veiga de Almeida (UVA). Pesquisador da Fundação Casa de Rui Barbosa (FCRB) e do Conselho Nacional de Desenvolvimento Científico e Tecnológico (CNPq).

\footnotetext{
${ }^{16}$ É ilustrativa a esse respeito a anedota narrada pelo ex-presidente Fernando Henrique Cardoso: “Sobre a 'esquerda' e a 'direita' no Brasil, há anos eu repito a frase que ouvi do historiador Sérgio Buarque de Holanda quando examinava uma tese de livre-docência sobre a política brasileira no Império. No trabalho, o autor confrontava o pensamento liberal, o conservador e o progressista. Sérgio, referindo-se a um personagem simbólico de nossos conservadores naquele período, perguntou com certa ironia ao candidato: você acredita que Bernardo Pereira de Vasconcelos lia Edmund Burke (um clássico do conservadorismo inglês, que via com maus olhos a Revolução Francesa)? Não, respondeu o próprio Sérgio, ele não era um verdadeiro conservador, não defendia ideias; ele era apenas um 'atrasado'" (Cardoso, 2016). Com efeito, depois da queda do Estado Novo, Holanda abandonou suas antigas simpatias pela herança monárquica e passou a criticá-la como responsável pela tradição autoritária que desembocara na ditadura varguista e no regime militar (Waizbort, 2011; Sanches, 2015).
} 


\section{Bibliografia}

ACD - Anais da Câmara dos Deputados.

ASI - Anais do Senado do Império.

ALENCAR, J. M. 1979. Discursos parlamentares. Brasília: Senado Federal. 1993. O tronco do ipê. São Paulo: Ática.

2009. Cartas de Erasmo. Rio de Janeiro: ABL.

ALONSO, A. 2009. Arrivistas e decadentes: o debate politico intelectual brasileiro na primeira década republicana. Novos estudos Cebrap, n. 85, pp. 131-148. ARAÚJO, V. L.; PIMENTA, J. P. 2009. História. In: FERES, J. (org.). Léxico da história dos conceitos políticos do Brasil. Belo Horizonte: Ed. UFMG.

BARBOSA, R. 1943. Discursos parlamentares: Câmara dos Deputados. Rio de Janeiro: Ministério da Educação e Saúde. (Obras completas, v. 6, t. I). . 1947. Queda do Império: Diário de Notícias. Rio de Janeiro: Ministério da Educação e Saúde. . 1948. Queda do Império: Diário de Notícias. Rio de Janeiro: Ministério da Educação e Saúde. 1956. Trabalhos jurídicos: estado de sítio. Rio de Janeiro: Ministério da Educação e Cultura.

. 1960/1966. Cartas de Inglaterra. São Paulo: Livraria Editora Iracema.

Cultura. 1962. Trabalhos diversos. Rio de Janeiro: Ministério da Educação e 1965. Trabalhos diversos. Rio de Janeiro: Ministério da Educação e Cultura. . 1974. Discursos parlamentares. Rio de Janeiro: Fundação Casa de Rui Barbosa. 1984. Embaixada a Buenos Aires. Rio de Janeiro: Fundação Casa de

Rui Barbosa. .1988. Abolicionismo. Rio de Janeiro: Fundação Casa de Rui Barbosa

BLUCHE, F. 2000. Le despotisme éclairé. Paris: Hachette.

BURKE, E. 1992. Further reflections on the Revolution in France. Edited by Daniel Ritchie. Indianapolis: Liberty Fund. . 1993. Pre-revolutionary writings. Edited by Ian Harris. Cambridge:

Cambridge University Press. 1999. Select works of Edmund Burke. Foreword and biographical note by Francis Canavan. Indianapolis: Liberty Fund. $4 \mathrm{v}$.

CANDIDO, A. 2004. Radicalismos. In: Vários escritos. Rio de

Janeiro: Duas Cidades.

CARDOSO, F. H. 2016. O certo e o errado. O Estado de S. Paulo, 7 fev. 2016. CARVALHO, J. M. 1999. Bernardo Pereira de Vasconcelos. São Paulo: Editora 34. 
CLAEYS, G. 2017. Some Nineteenth-Century appraisals of Burke's reflections: from Sir John Mackintosh to John Morley. In: FITZPATRICK M.; JONES, P. The reception of Edmund Burke in Europe. London: Bloomsbury Academic.

COL, N. 2017. "The climacteric event in our history": aspects of Burke's reception in France. In: FITZPATRICK, M.; JONES, P. The reception of Edmund Burke in Europe. London: Bloomsbury Academic.

COLLINI, S.; WINCH, D.; BURROW, J. 1983. That noble science of politics: a study in nineteenth century intellectual history. Cambridge: Cambridge University Press.

COSER, I. 2008. Visconde de Uruguai: centralização e federalismo no Brasil (1823-1866). Belo Horizonte: Ed. UFMG.

COURTNEY, C. P. 2017. Edmund Burke and the writings of Benjamin Constant. In: FITZPATRICK, M.; JONES, P. The reception of Edmund Burke in Europe. London: Bloomsbury Academic.

DWAN, D. 2012. Burke and utility. In: DWAN, D.; INSOLE, C. J. The Cambridge Companion to Edmund Burke. Cambridge/New York: Cambridge University Press.

FERREIRA, G. N. 1999. Centralização e descentralização no Império: o debate entre Tavares Bastos e o Visconde de Uruguai. São Paulo: Editora 34.

FITZPATRICK M.; JONES, P. 2017. The reception of Edmund Burke in Europe.

London: Bloomsbury Academic.

FREEDEN, M. 1996. Ideologies and political theory: a conceptual approach.

Oxford, Oxford University Press. . 2003. Ideology: a very short introduction. Oxford: Oxford University Press.

FURET, F. 1988. La Révolution Française. De Turgot à Napoléon (1770-1815). Paris: Hachette.

GRIFFITHS, R. 1988. Le centre perdu: Malouet et les monarchiens dans la Révolution française. Grenoble: Presses Universitaires de Grenoble.

HARTZ, L. 1991. The liberal tradition in America. New York: Harverst Books. HIMMELFARB, G. 2005. Roads to modernity: the British, French and American Enlightenments. New York: Vintage Books.

JANCSÓ, I. 2002. A construção dos Estados nacionais na América

Latina: apontamentos para o estudo do Império como projeto. In: SZMRECSÁNYI, T.; LAPA, J. R. A. (orgs.). História econômica da Independência e do Império. 2. ed. Rev. São Paulo: Hucitec/Edusp. KIRSCHNER, T. C. 2003. Burke, Cairu e o Império do Brasil. In: JANCSÓ, I. (org.). Brasil: formação do Estado e da Nação. São Paulo: Hucitec.

LASKI, H. 1973. O liberalismo europeu. Tradução de Álvaro Cabral. São Paulo: Mestre Jou. 
LISBOA, J. S. 1822. Extratos das obras políticas e econômicas do grande Edmund Burke. 2. ed. mais correta. Lisboa: A Nova Impressão da Viúva Neves e Filho. LYRA, M. L. V. 1994. A utopia do poderoso Império: Portugal e Brasil, bastidores da política: 1798-1822. Rio de Janeiro: Sette Letras.

LYNCH, C. E. C. 2005. O discurso político monarquiano e a recepção do conceito de poder moderador no Brasil. Dados - Revista de Ciências Sociais, Rio de Janeiro, v. 48, n. 3, pp. 611-54. 2008. O pensamento conservador ibero-americano na era das independências (1808-1850). Lua Nova, n. 74, pp. 59-92. . 2011. Os órfãos de Montesquieu: o constitucionalismo esquecido dos monarquianos franceses (1789). Revista Estudos Políticos, Rio de Janeiro, n. 2, pp. 81-101. . 2012a. O caminho para Washington passa por Buenos Aires: a recepção do conceito argentino de estado de sítio e seu papel na construção da República brasileira. RBCS - Revista Brasileira de Ciências Sociais, v. 27, n. 78, pp. 149-96. 2012b. O Império é que era a República: a Monarquia republicana de Joaquim Nabuco. Lua Nova, n. 85, pp. 277-311.

2014. Entre o liberalismo monárquico e o conservadorismo republicano: a democracia impossível de Rui Barbosa. In: Da monarquia à oligarquia: história institucional e pensamento político brasileiro (1822-1930). São Paulo: Alameda.

2015. Modulando o tempo histórico: Bernardo Pereira de Vasconcelos e conceito de "regresso" no debate político-parlamentar brasileiro. Almanack, Guarulhos, n. 10, pp. 314-34.

MACAULAY, T. B. 1978. Mill's essay on government: utilitarian logic and politics. In: LIVELY, J.; REES, J. (eds.). Utilitarian logic and politics. Oxford: Clarendon Press.

MACIAG, D. (ed.). 2013. Edmund Burke in America. The contested career of the father of the modern conservatism. Ithaca, NY: Cornell University Press.

MARTINS, W. 1974. História da inteligência brasileira. v. II. São Paulo: Cultrix.

MAGALHÃES Júnior, R. 1977. José de Alencar e sua época. 2. ed., corrigida e aumentada. Rio de Janeiro: Civilização Brasileira.

MANNHEIM, K. 1968. Ideologia e utopia. Rio de Janeiro: Zahar.

MATTOS, I. R. 1994. O tempo Saquarema. 3. ed. Rio de Janeiro: Acess.

MAXWELL, K. 2001. A devassa da Devassa: a Inconfidência Mineira, Brasil-

Portugal, 1750-1808. 5. ed. Tradução de João Maia. São Paulo: Paz e Terra.

MORLEY, J. 1888. Burke. London: Macmillan.

NABUCO, J. 1949a. Balmaceda. São Paulo: Progresso Editorial. 
1949b. Cartas aos Amigos. Volume II. São Paulo, Progresso

Editorial.

1997 [1897]. Um estadista do Império. Rio de Janeiro: Topbooks. 1999. A Abolição e a República. Organizado e apresentado por

Manuel Correia de Andrade. Recife: UFPE.

2004. Minha formação. Belo Horizonte: Itatiaia.

NEVES, L. M. B. P. 2003. Corcundas e constitucionais: a cultura política da independência (1820-1822). Rio de Janeiro: Revan.

PALTI, E. J. 2008. El pecado de la teoría: una respuesta a José Antonio

Aguilar. Istor - Revista de Historia Internacional, año IX, n. 35, pp. 137-54.

POCOCK, J. 1985. Virtue, commerce, and history: essays on political thought and history, chiefly in the Eighteenth Century. Cambridge: Cambridge University Press. 1987. Introduction. In: BURKE, E. Reflections on Revolution in

France. Indianapolis/Cambridge: Hackett. 2003. Barbarism and religion. v. 1. New York: Cambridge University Press.

RAYNAUD, P. 1993. Burke, Edmund, 1729-1797. Reflexões sobre a

Revolução Francesa, 1790. In: CHÂTELET, F.; DUHAMEL, O.; PISIER, E. (orgs.). Dicionário de obras políticas. Tradução de Glória de C. Lins e Manoel Ferreira Paulino. Rio de Janeiro: Civilização Brasileira.

RICUPERO, B. 2004. O romantismo e a ideia de nação no Brasil (1830-1870).

São Paulo: Martins Fontes.

2010. O conservadorismo difícil. In: FERREIRA, G. N.; BOTELHO,

A. (orgs.). Revisão do pensamento conservador. São Paulo: Hucitec.

SANCHES, D. 2015. Debates sobre Cairu: política e historicidade em

Raízes do Brasil. Revista Ágora, Vitória (ES), n. 21, p. 98-210.

SANI, G. 1998. Cultura política. In: BOBBIO, N.; MATTEUCCI, N.;

PASQUINO, G. Dicionário de Política. 11. ed. v. 1. Tradução de Carmen

C. Varriale e outros. Brasília: Ed. UnB.

TRIGUEIRO, G. 2016. Edmund Burke remodelado. Amálgama, n. 12.

Disponível em: <https://www.revistaamalgama.com.br/12/2016/

resenha-edmund-burke-redescobrindo-um-genio-russell-kirk/>. Acesso em: 3 mar. 2017.

2017. Neoconservadorismo versus paleoconservadorismo: o papel dos

Estados Unidos no sistema internacional e a identidade conservadora norteamericana. Tese de doutorado. Rio de Janeiro: UFRJ.

VASCONCELOS, B. P. 1999. Bernardo Pereira de Vasconcelos. Introdução e

seleção de José Murilo de Carvalho. São Paulo: Editora 34.

VENTURI, F. 2003. Utopia e reforma no Iluminismo. Tradução de Modesto

Florenzano. Bauru: EDUSC. 
VISCONDE DE CAIRU [José da Silva Lisboa]. 2001. Visconde de Cairu. Organização e introdução de Antônio Penalves Rocha. São Paulo: Editora 34.

WATKINS, F. M.; KRAMNICK, I. 1981. A idade da ideologia: pensamento político de 1750 até o presente. Tradução de Rosa Maria e José Viegas. Brasília: Ed. UnB.

WATTS, D. 2002a. Tories, unionists and conservatives, 1815-1914. London: Hodder \& Stoughton. 2002b. Whigs, radicals and liberals, 1815-1914. London: Holler \& Stoughton.

WAIZBORT, L. 2011. O mal-entendido da democracia: Sérgio Buarque de Holanda, Raízes do Brasil, 1936. RBCS - Revista Brasileira de Ciências Sociais, v. 26, n. 76, pp. 39-62.

WOOD, G. 2009. Empire of liberty: a history of the early Republic, 1789-1815. Oxford: Oxford University Press. 


\title{
CONSERVADORISMO CALEIDOSCÓPICO: EDMUND BURKE E 0 PENSAMENTO POLÍTICO DO BRASIL OITOCENTISTA
}

\author{
CHRISTIAN EDWARD CYRIL LYNCH
}

Resumo: O presente artigo objetivou estudar a recepção das ideias de Edmund Burke no pensamento político brasileiro de matriz oitocentista. As evidências apresentadas pretendem revelar a forma inteligente e variada pela qual seus argumentos foram considerados por seus leitores brasileiros, no período em questão, levando-se em conta suas particularidades de agenda política e as diferenças entre as sociedades do Brasil e da Grã-Bretanha. Percebe-se a densidade semântica do conceito de conservadorismo: não existiu apenas um, mas diversos conservadorismos, muitas vezes conflitantes entre si: reformismo ilustrado, conservadorismo estatista, conservadorismo culturalista e liberalismo conservador. Ao final, o artigo tece considerações sobre a natureza problemática da ideologia conservadora em um país periférico, visto como periférico, atrasado e carente de modernização. Por essa razão, o conservadorismo hegemônico tenderia a assumir contornos típicos de ideologias modernizadoras ordeiras, que combinam constitucionalismo e autoritarismo.

Palavras-chave: Burke; Teoria Política; História dos Conceitos; Pensamento Político Brasileiro; Pensamento Social no Brasil; Conservadorismo.

\section{A CONSERVATIVE KALEIDOSCOPE: EDMUND BURKE AND THE BRAZILIAN NINETEENTH-CENTURY POLITICAL THOUGHT}

Abstract: This article aimed at studying the reception of Edmund Burke's thought in the Brazilian nineteenth-century political debate. The presented evidence intends to reveal the varied and intelligent way Brazilian readers considered Burkean arguments, taking into account 
their particular political agenda and the differences between Brazilian and British societies. The semantic density of the conservatism concept is seen: there was not only a single and coherent conservatism, there were many ones: enlightened absolutism, State conservatism, cultural conservatism, and tactical conservative liberalism. Finally, the article reflects on the problematic nature of conservative ideology in a peripheral country, which is seen by its politicians as backward and in need of modernization. Therefore, the hegemonic Brazilian conservatism tended to assume typical contours of orderly modernizing ideologies that combine constitutionalism and authoritarianism.

Keywords: Burke; Political Theory; History of Concepts; Brazilian Political Thought; Brazilian Social Thought; Conservatism.

Recebido: 26/07/2016 Aprovado: 26/01/2017 